InfoTekJar :Jurnal Nasional

InformatikadanTeknologiJaringan

\title{
Solusi Payment Online Berbasis Cloud Accounting Pada Menajemen Berbasis Perguruan Tinggi
}

\author{
Untung Rahardja ${ }^{1}$, Po Abas Sunarya ${ }^{1}$, Qurotul Aini, Shylvia Ratna Dewi ${ }^{2}$ \\ ${ }^{1}$ Dosen STMIK Raharja Jurusan Sistem Informasi \\ ${ }^{2}$ Mahasiswa STMIK Raharja Jurusan Sistem Informasi
}

\section{KEYWORDS}

Cloud Accounting, Journal Payment, Cashless

\section{CORRESPONDENCE}

Phone:

E-mail: untung@raharja.info,

\section{A B S T R A C T}

Dalam memasuki era disruptif 4.0 penyampaian informasi yang cepat dan akurat tentunya sangat dibutuhkan, salah satu diantaranya adalah pada bidang keuangan dan akuntansi karena mengandung informasi berupa tagihan pembayaran dan laporan keuangan guna pengambilan sebuah keputusan. Namun pada beberapa Perguruan Tinggi teridentifikasi 2 (dua) permasalahan yaitu penyebaran tagihan dilakukan secara konvensional sehingga informasi yang diterima tidak akurat dan real time serta mahasiswa melakukan pembayaran dengan cara menukar resi pembayaran dengan sebuah kwitansi. Sehingga kedua hal tersebut dapat mengakibatkan data dan laporan yang berserakan serta tidak efisien dalam segi waktu dan biaya. Dalam mencegah kedua permasalahan tersebut dibutuhkan sebuah cloud accounting guna menyebarkan tagihan dan melakukan pembayaran dapat dilakukan secara online. Jurnal.id merupakan salah satu cloud accounting dimana memiliki fitur Jurnal Payment yang memungkinkan pihak kasir dapat dengan mudah mengirim tagihan pembayaran melalui $E$ mail dan mahasiswa melunasi tagihan secara online. Adapun pemecahan masalah guna menyelesaikan permasalahan ini yaitu digunakan metode analisis SWOT dan 8 (delapan) studi pustaka yang dilakukan pada penelitian ini. Diharapkan dengan adanya Jurnal Payment dapat memudahkan dalam proses transaksi pembayaran guna menghasilkan data yang akurat dan real time. Sehingga dapat memudahkan dua belah pihak yaitu pihak kasir dalam proses penyebaran tagihan dan penginputan receive payment karena sudah tersinkronisasi secara otomatis serta pihak mahasiswa dalam melunasi pembayaran tagihan secara online dan keuangan menjadi lebih cashless, efektif dan efisien.

In In entering the disruptive era 4.0, fast and accurate information delivery is certainly needed, one of which is in the field of finance and accounting because it contains information in the form of payment bills and financial statements in order to make a decision. However, in some universities 2 (two) problems were identified, namely the spread of bills carried out conventionally so that the information received was inaccurate and real time and the students made payments by exchanging payment receipts with a receipt. So that both of these things can lead to data and reports that are scattered and inefficient in terms of time and cost. In preventing these two problems, an cloud accounting is needed to spread bills and make payments can be made online. Jurnal.id is one of the cloud accounting which has a Payment Journal feature that allows the cashier to easily send bills for payments via E-mail and students pay bills online. The problem solving is to solve this problem which is used the SWOT analysis method and 8 (eight) literature studies conducted in this study. It is expected that the Payment Journal can facilitate the payment transaction process to produce accurate and real time data. So that it can facilitate the two parties namely the cashier in the process of distributing bills and receiving payment input because it has been synchronized automatically and the students in paying off online and financial bill payments become more cashless, effective and efficient.

\section{PENDAHULUAN}

Sebuah institusi pendidikan pada era modern seperti sekarang ini, tidak dapat dipungkiri sudah sangat pesat bahkan memasuki perkembangan teknologi dalam bidang akuntansi.
Pengembangan dan pembaharuan sistem pada perguruan tinggi terus menerus dilakukan sehingga membuat sistem akuntansi dirasa mengalami kemajuan yang sangat signifikan. Sehingga sistem tersebut tentunya dapat membuat sebuah perubahan pada era yang awal mulanya masih manualisasi atau konvensional menuju era yang tentu saja lebih modern dan komputerisasi 
dalam berbagai bidang pendidikan dan lain-lain.

Metode pembayaran dalam Layanan Keuangan Mahasiswa pada sistem yang berjalan sebelumnya memiliki beberapa kelemahan diantaranya untuk saat ini tidak efektif dalam segi waktu dan biaya, mahasiswa membutuhkan banyak waktu untuk pergi ke bank melakukan transfer pembayaran

Kemudian kembali ke kasir untuk menukar resi pembayaran dengan sebuah kwitansi sehingga tidak efektif dan efisien. Kemudian pada sisi kasir saat ini tidak efektif dari segi proses pembukuan karena membutuhkan kurang lebih 3 (tiga) kali pindah buku karena belum adanya sistem yang secara otomatis dalam melakukan sinkronisasi.

Untuk mengatasi beberapa kelemahan tersebut dirasa sangat dibutuhkan sebuah perubahan dalam berbagai aspek, salah satunya dalam bentuk penyebaran informasi tagihan pembayaran sehingga informasi dapat dinilai lebih efektif dan efisien [12]. Jurnal merupakan salah satu Cloud Accounting dalam bidang akuntansi dengan fasilitas dalam menyajikan laporan keuangan secara lengkap, seperti neraca keuangan, bentuk fasilitas guna memudahkan pihak kasir dalam menyebarkan tagihan pembayaran dan mahasiswa melunasi tagihan pembayaran secara online telah hadir sebuah Software Jurnal (Cloud Accounting).

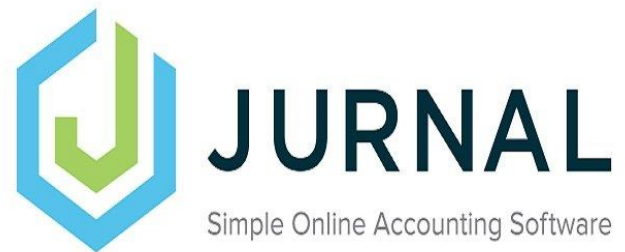

Gambar 1 . Logo Software Jurnal (Cloud Accounting)

Jurnal.id merupakan Cloud Accounting dimana dapat mempermudah dalam proses pencatatan laporan keuangan berbasis online dan cloud. Sistem Jurnal.id memiliki keamanan dengan teknologi setara bahkan lebih baik dari yang digunakan pada Bank. Menggunakan Encryption AES256 guna data yang terinput pada sistem tidak dapat dilihat secara umum oleh pihak yang tidak memiliki wewenang. 2056-bit SSL Certificate digunakan dalam mengamankan koneksi internet pada sistem [13]. Jurnal.id juga memiliki fasilitas Jurnal Payment yang dapat mempermudah pihak kasir dalam menyebar tagihan dan menginput pembayaran serta memudahkan mahasiswa dalam melunasi tagihan pembayaran secara online. Metode pembayaran pada Jurnal Payment dapat melalui virtual account dan kartu kredit, jika pembayaran dilakukan via virtual account maka pembayaran akan diterima oleh sistem selama 1 x 24 Jam dimulai pada tanggal pembayaran. Namun jika pembayaran dilakukan via kartu kredit maka pembayaran akan diterima oleh sistem selama 7 x 24 jam dimulai pada tanggal transaksi

Menurut Rahardja, U. (2018), sistem GO+ adalah sebuah sistem informasi keuangan baru yang lahir pada Perguruan Tinggi dan merupakan sebuah sistem yang diharapkan mampu memudahkan dalam hal pengecekan tagihan biaya registrasi dan pembayaran SKS oleh mahasiswa secara online dan mandiri [1]. GO+ (Green Orchestra Plus) merupakan sistem informasi tagihan pembayaran mahasiswa yang dapat diakses pada menu RBR (Rincian BiayaRegistrasi) dan RBK (Rincian BiayaKuliah), serta terdapat juga Menu Konfirmasi Pembayaran. Selain itu pada sistem GO+ (Go plus) juga dapat menampilkan informasi penting seputar pembayaran mahasiswa seperti tanggal jatuh tempo serta nomor rekening Perguruan Tinggi secara online dan mandiri.

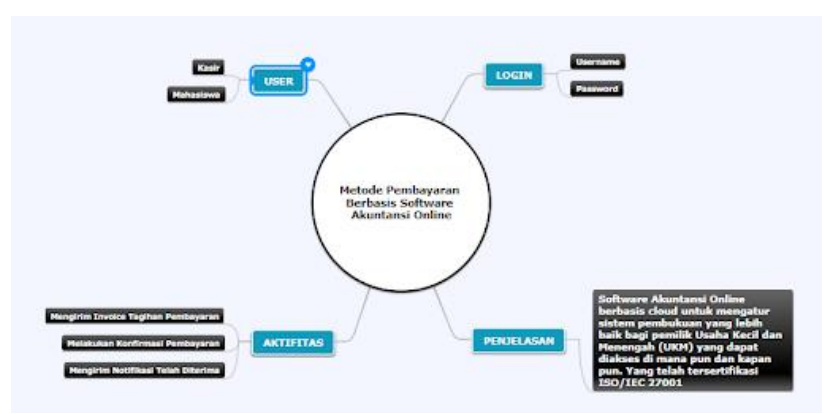

Gambar 2. Mind Mapping Metode

Pembayaran Berbasis Cloud Accounting

Jurnal.id merupakan Cloud Accounting dimana dapat mempermudah dalam proses pencatatan laporan keuangan berbasis online dan cloud. Sistem Jurnal.id memiliki keamanan dengan teknologi setara bahkan lebih baik dari yang digunakan pada Bank. Menggunakan Encryption AES256 guna data yang terinput pada sistem tidak dapat dilihat secara umum oleh pihak yang tidak memiliki wenang. 2056-bit SSL Certificate digunakan dalam mengamankan koneksi internet pada sistem [13]. Jurnal.id juga memiliki fasilitas Jurnal Payment yang dapat mempermudah pihak kasir dalam menyebar tagihan dan menginput pembayaran serta memudahkan mahasiswa dalam melunasi tagihan pembayaran secara online. Metode pembayaran pada Jurnal Payment dapat melalui virtual account dan kartu kredit, jika pembayaran dilakukan via virtual account maka pembayaran akan diterima oleh sistem selama 1 x 24 Jam dimulai pada tanggal pembayaran. Namun jika pembayaran dilakukan via kartu kredit maka pembayaran akan diterima oleh sistem selama 7 x 24 jam dimulai pada tanggal transaksi.

Menurut Rahardja, U. (2016), literature Review adalah berupa buku atau bahan yang tertulis, membahas mengenai karya ilmiah yang memiliki topik penelitian bersifat relevan dengan topik penulis sebelumnya. Karena pada sebelumnya sudah banyak peneliti yang melakukan penelitian mengenai Metode Pembayaran [2] .Dalam sebuah penelitian mengenai Metode Pembayaran Berbasis Cloud Accounting seperti ini penulis melakukan studi pustaka sebagai salah satu dari penerapan metode penelitian serta untuk menunjang metode penelitian yang akan dilakukan. Berikut ini adalah 8 (delapan) literature ilmiah yang memiliki kolerasi searah atau relevan dan digunakan sebagai sumber dalam penelitian ini diantaranya:

1. Penelitian yang dilakukan oleh Yusup, Rahardja, U., dan Oktaviani, S., (2014), yang berjudul "GO+ Dalam Menunjang INT+ Untuk Pengelolaan Data CMB pada Perguruan Tinggi” Penelitian ini mengulas tentang sebuah sistem INT+ yang dapat digunakan secara online guna menunjang dalam mengelola data Calon Mahasiswa Baru (CMB) maupun membership yang dapat diakses pada lingkungan Perguruan Tinggi Raharja oleh Divisi Marketing. Terdapat 3 (tiga) tujuan dalam penelitian berikut ini 
yaitu tujuan pertama yaitu guna meningkatkan kegiatan promosi Perguruan Tinggi Raharja kepada Calon Mahasiswa Baru (CMB) yang ingin mendaftar, kemudian tujuan kedua yaitu untuk mendukung dan menunjang pengelolaan data diri berupa nama, Email dan nomor telepon dari Calon Mahasiswa Baru (CMB), dan tujuan yang ketiga yaitu guna mempermudah dua belah pihak yaitu pihak Calon Mahasiswa Baru (CMB) dan Divisi Marketing karena dapat meningkatkan kinerja personil Marketing. Pada proses implementasi dari penelitian ini dapat ditampilkan berupa prototype atau langkah-langkah bagaimana GO+ dengan INT + dapat bekerja, sehingga peneliti dapat menyimpulkan bahwa GO+ dengan INT+ dapat memudahkan dan memaksimalkan kinerja pada Divisi Marketing [3].

2. Penelitian yang dilakukan oleh Rahardja, U., Harahap, E. P., dan Pratiwi, S., (2018), yang berjudul "Pemanfaatan Mailchimp Sebagai Trend Penyebaran Informasi pembayaran bagi Mahasiswa di Perguruan Tinggi" Penelitian ini mengulas tentang sebuah fasilitas yang digunakan pada Perguruan Tinggi Raharja dan disediakan oleh Rinfo yaitu Mailchimp yang merupakan salah satu tool digital marketing yang dapat menjadi trend terbaru dikalangan IT guna memudahkan mahasiswa dalam menyebarkan berbagai informasi secara akurat, real time, efektif dan efisien. Berdasarkan analisa terdapat 3 (tiga) permasalahan pada penelitian berikut ini, permasalahan yang pertama yaitu penyebaran berbagai informasi seperti jadwal seminar, dan yang paling penting perihal jatuh tempo pembayaran di Perguruan Tinggi Raharja masih dilakukan dengan manual, permasalahan yang kedua yaitu belum maksimal dan kurangnya penggunaan tool pada divisi marketing dengan baik, proses implementasi tool pada divisi marketing belum berlangsung secara merata pada Perguruan Tinggi Raharja. Dengan adanya metode penelitian ini diharapkan permasalahan yang telah diuraikan diatas dapat terpecahkan dengan baik dan menghasilkan implementasi penggunaan Mailchimp dalam penyebaran informasi jatuh tempo dapat bermanfaat bagi seluruh kalangan luas di Perguruan Tinggi Raharja [4].

3. Penelitian yang dilakukan oleh Rahardja, U., Aini, Q., dan Thalia, M, B., (2018), yang berjudul "Penerapan Menu Konfirmasi Pembayaran Online Berbasis Yii pada Perguruan Tinggi" Penelitian ini mengulas tentang sebuah form konfirmasi pembayaran pada Perguruan Tinggi Raharja dengan menggunakan Yii Framework 2 pada fitur CRUD (Create, Read, Update, Delete) guna mempermudah dua belah pihak yaitu pihak kasir dalam meningkatkan pelayanan kepada mahasiswa dan juga pihak mahasiswa dalam hal konfirmasi setelah melakukan pembayaran. Adapun 3 (tiga) kelebihan yang dihasilkan pada penelitian berikut ini yaitu yang pertama pada menu form konfirmasi pembayaran ini dirancang menggunakan website sehingga dapat memudahkan user dalam mengakses kapan dan dimanapun (User friendly), kelebihan yang kedua yaitu adanya pilihan metode pembayaran dan jumlah tagihan pembayaran guna memudahkan user dalam mendapatkan informasi dan apabila ingin melakukan transaksi, kelebihan yang ketiga yaitu adanya tampilan menu hasil input atau faktur pembayaran oleh user sehingga dapat memastikan kebenaran data yang dimasukkan oleh user. Maka mengimplementasikan sebuah form konfirmasi pembayaran online dapat memberikan sebuah informasi tagihan pembayaran secara tepat, akurat, dan real time kepada mahasiswa, selain itu juga memberikan kemudahan pada divisi keuangan pada Layanan Keuangan Mahasiswa (LKM) perihal pengecekan transaksi yang masuk pada saat mahasiswa melakukan transfer pembayaran tanpa perlu dilakukan input secara manual [5].

4. Penelitian yang dilakukan oleh Tiara, K., Nurhaeni, T., dan Faradisa, Y., (2017), yang berjudul "Penerapan GO+ Berbasis Web untuk Meningkatkan Mutu Pelayanan Lembaga Keuangan Mahasiswa" Penelitian ini mengulas tentang sebuah sistem Green Orchestra Plus (GO+) guna menampilkan informasi perihal tagihan pembayaran perkuliahan yang dapat diakses secara online oleh mahasiswa kapanpun dan dimanapun. Dengan adanya GO+ pada Perguruan Tinggi Raharja mahasiswa dapat dengan mudah mengetahui informasi perihal tagihan pembayaran yang harus dilunasi, dapat dianalisa permasalahan dari penelitian yang dilakukan yaitu pada saat mahasiswa ingin mengetahui tagihan pembayaran yang harus dilunasi mahasiswa harus mengantri pada BOX SIS dengan cara swipe Pribadi Raharja Card mereka, adapun cara lain yaitu sama hal nya dengan cara pertama yaitu harus mengantri untuk bertanya langsung pada pihak kasir, kedua cara tersebut sangat tidak real time, efektif dan efisien dalam segi waktu tentunya. Dalam penyediaan sistem GO+ ini maka peneliti mengharapkan mampu memberikan kemudahan dalam memberikan informasi tagihan pembayaran yang harus dilunasi bagi seluruh mahasiswa di Perguruan Tinggi Raharja [6].

5. Penelitian yang dilakukan oleh Purves, T., Vandrevala, Z., Romanek, T., dan Kim, J., (2013), yang berjudul "Remote Portal Bill Payment Platform Apparatuses, Methods and Systems" Penelitian ini mengulas tentang sebuah Remote Portal Bill Payment yang dapat mengubah pesan permintaan berupa tagihan pembayaran pengguna melalui fasilitas yang telah disediakan seperti komponen-komponen Bill Pay yang dapat menjadi tagihan transaksi pembayaran serta penggunaan tagihan pembayaran dan sejenisnya. Implementasi yang dilakukan dalam penelitian ini adalah terdiri dari mendapatkan sebuah permintaan tagihan pembayaran dari komponen tagihan pembayaran tersebut yang digunakan dalam situs portal hosting, kemudian dapat dikatakan komponen tagihan pembayaran dapat dioperasikan secara independent oleh pihak penagihan, permintaan transaksi tagihan pembayaran termasuk kedalam informasi tagihan yang diterbitkan oleh pihak biller dan pembayaran yang dapat mengindentifikasikan informasi, langkah selanjutnya menentukan jenis komponen tagihan pembayaran, melakukan verifikasi mengenai informasi tagihan termasuk total jumlah pembayaran yang harus dilunasi dan jenis komponen yang akan dibayarkan, untuk langkah terakhir mentransfer total jumlah dana yang telah disetujui kepada akun biller dari akun pembayaran [7].

6. Penelitian yang dilakukan oleh May, J. dan Flint, I. (2009), yang berjudul "Method and Apparatus for Facilitating Online Payment Transactions in a Network-Based Transaction Facility Using Multiple Payment Instruments" Penelitian ini mengulas tentang sebuah metode dan peralatan yang memiliki fasilitas dalam transaksi pembayaran online antar sesama peserta yang menggunakan fasilitas transaksi berbasis jaringan. Dapat dijelaskan tahap-tahap dalam pemrosesan penelitian berikut ini dalam fasilitas transaksi online berbasis jaringan pengguna dapat mengidentifikasi berbagai instrumen pembayaran yang telah 
disediakan oleh sistem dengan cara informasi antarmuka untuk langkah selanjutnya informasi tentang opsi pembayaran dapat diterima melalui peserta pertama melalui perantara jaringan komunikasi. Informasi opsi pembayaran tersebut dapat diterima melalui peserta pertama guna menerima pembayaran yang diberikan dari peserta kedua melalui berbagai macam pilihan instrumen pembayaran yang tersedia. Informasi penagihan secara pribadi tersebut menyangkut perihal instrumen pembayaran yang telah dipilih oleh peserta kedua melalui instrumen pembayaran yang telah ditentukan dari peserta yang pertama [8].

7. Penelitian yang dilakukan oleh Jamison, E. W., Fortney, D. S., Vasavada, D. A., dan Kosowski, A., (2011), yang berjudul "System and Method for Obtaining Customer Bill Information and Facilitating Bill Payment at Biller Websites" Penelitian ini mengulas tentang sebuah sistem pembayaran tagihan elektronik dan pembayaran elektronik terpadu (EBPP) guna memperoleh tagihan bagi pelanggan yang dapat meliputi individu, sebuah organisasi dan bisnis serta memungkinkan melakukan pembayaran dengan kartu kredit untuk dapat diproses pada situs web biller atas nama pelanggan tersebut. Sistem ini dapat terintegrasi dengan tagihan pelanggan mulai dari jenis billers kertas, situs web biller yang dapat digosok, dan billers elekronik, dengan pelanggan yang menyediakan informasi akses sehingga sistem (EBPP) ini dapat terintegrasi dengan menggunakan perangkat lunak. Sistem ini apalagi telah terintegrasi dapat memungkinkan pelanggan dengan secara otomatis dapat membuat akun pengguna di situs web biller tersebut dengan pelanggan yang telah menyediakan informasi akses dan informasi akun keuangan pengguna seperti contoh kartu kredit atau kartu debit sehingga pelanggan dapat mengakses situs web biller serta dapat memulai proses pembayaran yang dilakukan pada situs web biller [9].

8.Penelitian Penelitian yang dilakukan oleh Johnston, D., Schmidt, M., Grosman, I., dan Ransom, B., (2012), yang berjudul "Interactive Electronic Bill Payment System" Penelitian ini mengulas tentang sebuah sistem yang digunakan untuk mengkoordinasikan pengajuan dan pemrosesan sebuah tagihan menurut data pembayaran yang diprediksi berdasarkan sebuah rencana. Sistem ini dapat terdiri dari antarmuka penyedia dan basis data terpadu guna menerima rencana pembayaran prediktif yang telah dikirim melalui antarmuka penyedia. Sistem ini juga memiliki jenis permintaan pembayaran prediktif dari sebuah rencana yang telah disimpan dalam database, termasuk sejumlah parameter pembayaran prediktif. Terdapat juga mesin ajudikasi yang digabungkan ke dalam database yang telah terintegrasi, serta memiliki fasilitas fungsi penyisipan guna memasukkan parameter pembayaran prediktif ketika telah disimpan ke dalam database. Kemudian terdapat set aturan ajudikasi guna ajudikasi akhir dari data pembayaran prediktif dalam pembuatan sebuah tagihan. Sistem ini juga memiliki mesin alur kerja yang telah digabungkan ke dalam basis data terpadu guna mengkoordinasi pemrosesan tagihan elektronik serta dapat memperbarui mengenai informasi tagihan [10].

Berdasarkan 8 (delapan) literature review pada penelitian tersebut, bahwa metode pembayaran saat ini masih memerlukan pembaharuan pada sistem. Terdapat keunggulan pada Perguruan Tinggi yaitu telah diterapkan sistem pembayaran secara online, namun pihak kasir masih mengirim tagihan secara manual atau konvensional dan pihak mahasiswa masih menukar resi pembayaran dengan kwitansi sehingga tidak efektif bagi akuntan. Maka peneliti melakukan penelitian dan pengembangan sebuah sistem berupa metode pembayaran menggunakan Cloud Accounting dengan Jurnal.id pada Perguruan Tinggi

\section{METODE PENELITIAN}

Dalam merancang dan mengembangkan sebuah sistem terdapat beberapa hal penting yang perlu diperhatikan, diantaranya terdapat 2 (dua) metode penelitian guna mengatasi berbagai rumusan permasalahan yang ada maka didalam tahapan penelitian ini diterapkan beberapa metode.

Menurut Rahardja, U. (2016), secara umum analisa SWOT dapat diartikan sebagai metode yang digunakan untuk menilai kekuatan dan kelemahan dari tantangan yang dihadapi serta sumber daya yang dimiliki Perguruan Tinggi. Pada metode penelitian ini menggunakan analisa SWOT dimana pada analisa ini mengidentifikasi Strength (Kekuatan) dan Weakness (Kelemahan), Opportunities (Peluang) dan Threats (Ancaman) sebagaifaktor internal [18].

\begin{tabular}{|c|c|}
\hline Strength (S) & Weakness (W) \\
\hline $\begin{array}{l}\text { 1. Perguruan Tinggi berbasis Teknologi } \\
\text { 2. Menggunakan Cloud Accounting } \\
\text { Jurnal.id tersertifikasi ISO/IEC } 27001 \\
\text { 3. Jurnal.id dapat diakses secara online }\end{array}$ & $\begin{array}{l}\text { 1. Penyebaran tagihan dan pelunasan } \\
\text { tagihan masih secara konvensional } \\
\text { 2. Tidak diaktifkan fitur Jurnal } \\
\text { Payment } \\
\text { 3. Kasir dan mahasiswa beradaptasi } \\
\text { dengan sistem baru }\end{array}$ \\
\hline Opportunities (O) & Threats (T) \\
\hline $\begin{array}{l}\text { 1. Fitur Jurnal Payment memudahkan } \\
\text { kasir dan mahasiswa dalam } \\
\text { melakukan transaksi pembayaran } \\
\text { 2. Mengurangi kekeliruan data pada } \\
\text { penginputan receive payment karena } \\
\text { sudah otomatis tersinkronisasi }\end{array}$ & $\begin{array}{l}\text { 1. Tidak adanya jaringan/koneksi } \\
\text { internet } \\
\text { 2. Terjadinya penipuan dalam } \\
\text { pengiriman Invoice kepada } \\
\text { mahasiswa }\end{array}$ \\
\hline
\end{tabular}

Gambar 3. Tabel analisa SWOT

Metode Payment berbasis Cloud Accounting

Dengan membandingkan kekuatan dan kelemahan pada faktor internal sehingga dari metode analisa SWOT diatas dapat disimpulkan oleh peneliti, terdapat 4 (empat) strategi yaitu yang pertama Strength (Kekuatan) telah diterapkan adalah Perguruan Tinggi berbasis Teknologi, Menggunakan Sistem Cloud Accounting Jurnal.id dengan berbasis Cloud Accounting yang telah tersertifikasi ISO/IEC 27001, dan sistem Jurnal.id dapat diakses secara online kapanpun dan dimanapun. Dan yang kedua yaitu Weakness (Kelemahan) adalah penyebaran tagihan dan pelunasan tagihan masih dilakukan secara manual atau konvensional, Tidak diaktifkan fitur Jurnal Payment, sehingga pihak kasir dan pihak mahasiswa harus beradaptasi dengan sistem baru. Kemudian yang ketiga Opportunities (Peluang) adalah fitur Jurnal Payment memudahkan kasir dan mahasiswa dalam melakukan transaksi pembayaran, dan mengurangi kekeliruan data pada penginputan receive payment karena sudah otomatis tersinkronisasi dengan sistem Jurnal.id. Dan yang terakhir yaitu Threats (Ancaman) adalah khawatir karena tidak adanya jaringan atau koneksi internet, kemudian terjadinya penipuan atau pemalsuan dalam pengiriman invoice kepada mahasiswa. 


\section{HASIL DAN PEMBAHASAN}

Pada bagian hasil dan pembahasan ini akan dilakukan pengulasan mengenai analisa kebutuhan dari sistem yang dirancang berdasarkan dengan analisa permasalahan dan analisa yang dihasilkan, kemudian dilanjutkan dengan melakukan pengembangan sistem yang terdiri atas pemecahan permasalahan. Pada bagian akhir yaitu implementasi sistem yang menyajikan berupa screenshoot sistem Cloud Accounting yang telah digunakan dalam metode pembayaran tagihan mahasiswa.

\section{A. Analisa Permasalahan}

Pada sistem yang berjalan sebelumnya sudah cukup baik namun masih memiliki beberapa kekurangan seperti pada sisi mahasiswa, diharuskan melakukan pengecekan biaya tagihan pembayaran pada menu RBR (Rincian Biaya Registrasi) dan juga menu RBK (Rincian Biaya Kuliah) kemudian melakukan pembayaran pada Bank dan menukar resi pembayaran dengan kwitansi pada kasir sehingga kurang efisien dan tidak real time.

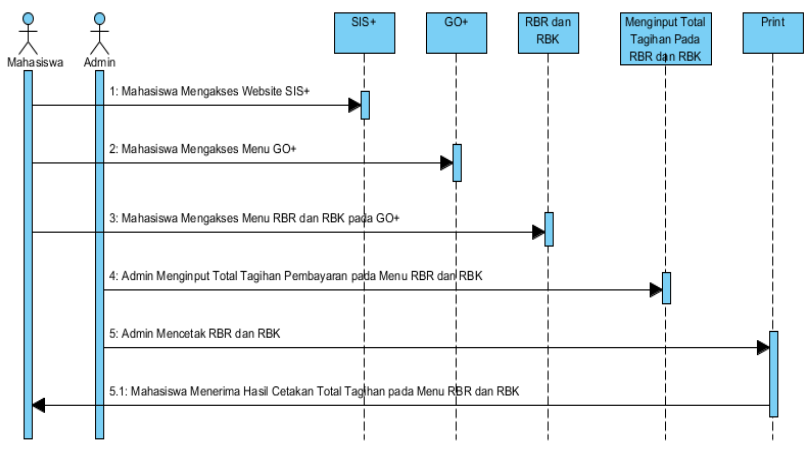

Gambar 4 . Sequence Diagram Sistem yang Berjalan

Penjelasan mengenai gambar diatas merupakan tampilan alur sistem pembayaran yang sedang berjalan saat ini. Adapun dari gambar alur diatas terdapat 2 (dua) aktor yang memiliki tugas dan tanggung jawab yang berbeda diantaranya yaitu Kasir dan Mahasiswa. Tugas dan tanggung jawab yang dimiliki masing-masing aktor berbeda yaitu Kasir menginput data dan total tagihan pembayaran pada Menu RBR (Rincian Biaya Registrasi) dan RBK (Rincian Biaya Kuliah) pada website GO+ kemudian mencetak Total Tagihan untuk didistribusikan pada Mahasiswa yang menanyakan perihal Tagihan Pembayaran. Kemudian Mahasiswa yang ingin melakukan pembayaran dapat melakukan transfer pada Bank dan menukar resi pembayaran dengan kwitansi pada kasir.

\section{B. Pemecahan Permasalahan}

Pada permasalahan yang telah dijelaskan oleh sequence diagram diatas dapat meminimalisir permasalahan pada sistem sebelumnya yaitu aktivasi Jurnal Payment pada sistem Jurnal.id, yang secara otomatis telah terintegrasi atau terkoneksi dengan sistem Jurnal.id sehigga dengan adanya Jurnal Payment, kasir dapat menyebarkan tagihan pembayaran secara online dan receive payment yang dilunasi oleh mahasiswa secara otomatis tersinkronisasi pada sistem.

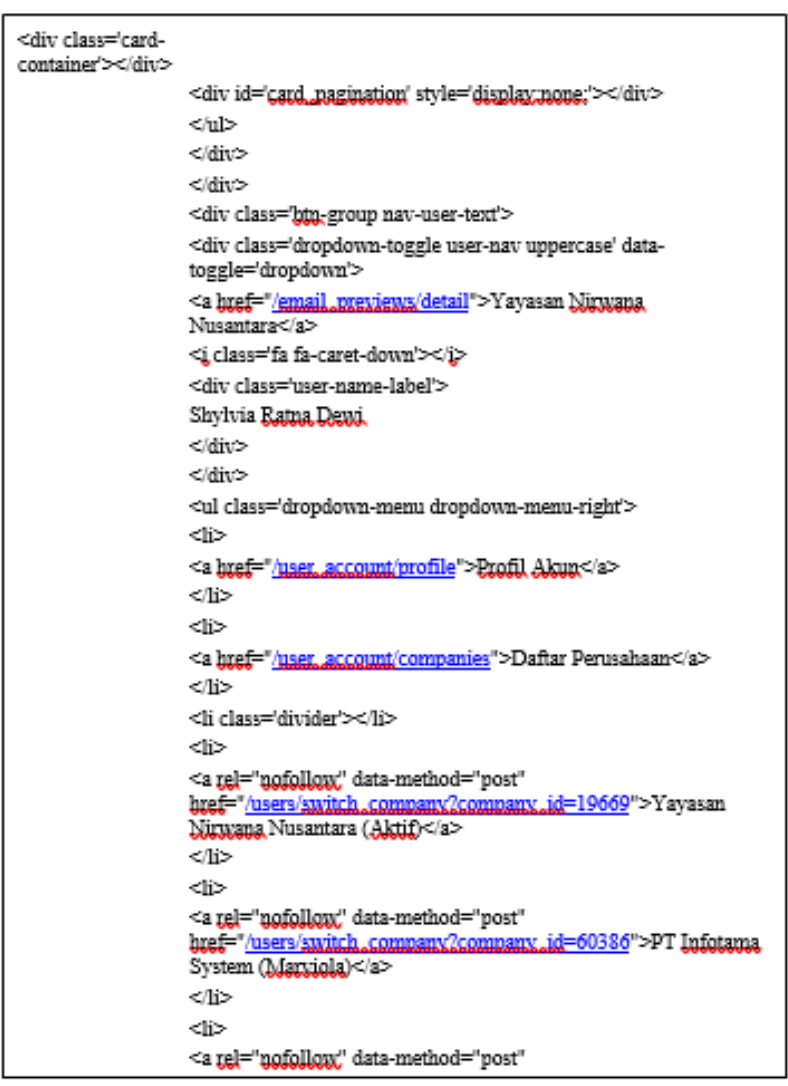

Gambar 5 .KonfigurasiVerifikasiPembayaran

Pada potongan Script HTML berikut telah dibuatkan link dimana sudah ada attribute yang akan direct pada Nomor Virtual Account masing-masing ketika mahasiswa ingin melakukan pembayaran tagihan. Sehingga setiap mahasiswa memiliki Nomor Virtual Account yang berbeda-beda dan dapat melakukan transaksi pembayaran secara online melalui Nomor Virtual Account masing-masing mahasiswa. Sehingga receive payment yang masuk sudah tersinkronisasi secara otomatis pada sistem dan pihak akuntan tidak perlu lagi menginput secara konvensional untuk melakukan rekonsiliasi. 


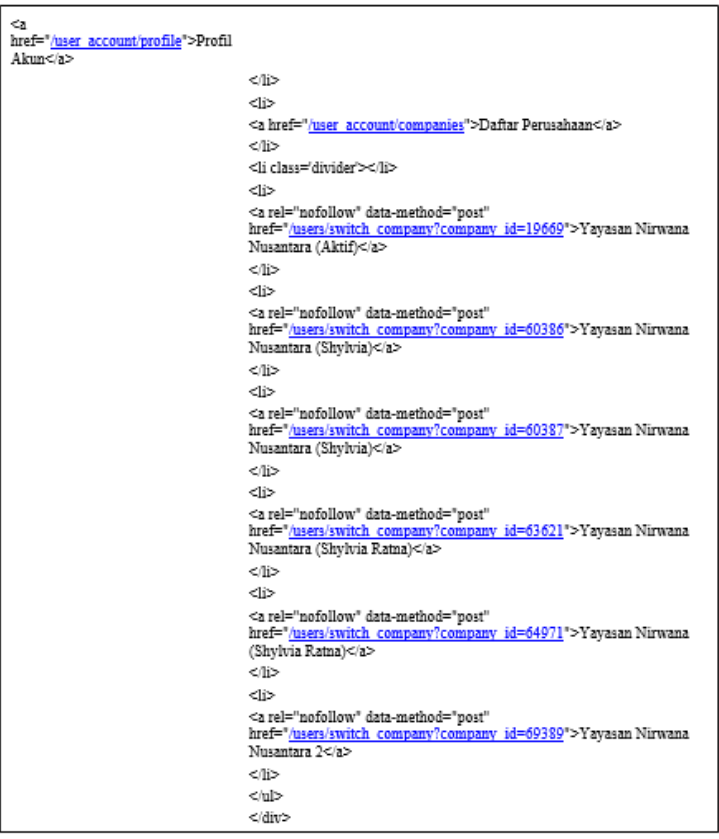

Gambar 6 . Konfigurasi Rincian pembayaran

Pada potongan Script HTML berikut telah dibuatkan link dimana sudah ada attribute yang akan direct pada Nomor Virtual Account masing-masing ketika mahasiswa ingin melakukan pembayaran tagihan. Sehingga setiap mahasiswa memiliki Nomor Virtual Account yang berbeda-beda dan dapat melakukan transaksi pembayaran secara online melalui Nomor Virtual Account masing-masing mahasiswa. Sehingga receive payment yang masuk sudah tersinkronisasi secara otomatis pada sistem dan pihak akuntan tidak perlu lagi menginput secara konvensional untuk melakukan rekonsiliasi.

\section{Implementasi}

Menurut Aini, Q. (2017), Dalam tahap implementasi perancangan sistem dapat berupaya menganalisa memproses atau mengirimkan data, menyimpan data, dan menghasilkan informasi. Perancangan sistem digunakan untuk menganalisa, merancang, dan mengimplementasikan peningkatanpeningkatan fungsi yang bisa dicapai melalui penggunaan sistem informasi terkomputerisasi [11].

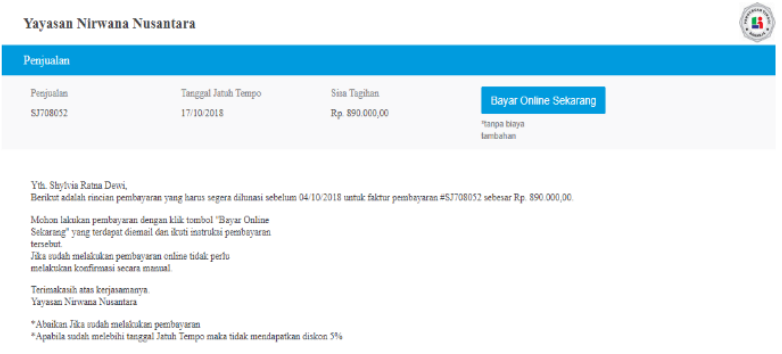

Gambar 7 . Tampilan Invoice Tagihan pada Email Mahasiswa

Sebelum mahasiswa melakukan pembayaran tagihan, pihak Layanan Keuangan Mahasiswa akan mengirimkan tagihan pembayaran yang harus dilunasi oleh mahasiswa melalui email mahasiswa sebelum tanggal jatuh tempo pembayaran pada bulan berikutnya. Kemudian apabila mahasiswa telah mendapatkan invoice dan rincian tagihan pembayaran langkah selanjutnya yaitu pilih tombol Bayar Online Sekarang.

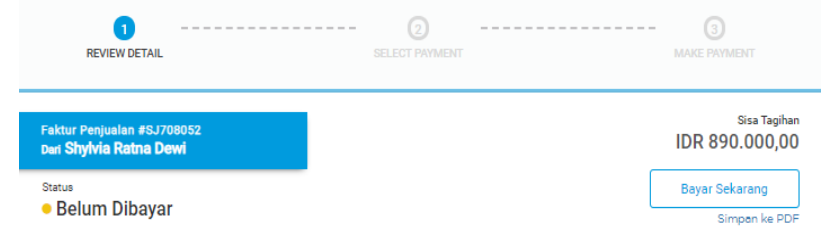

Gambar 8 . Halaman Select Payment Tagihan Mahasiswa

Setelah mahasiswa memilih tombol Bayar Online Sekarang, maka tampilan langkah selanjutnya yaitu melakukan pembayaran pada halaman select payment dimana terdapat penjelasan mengenai sisa tagihan yang harus dilunasi mahasiswa dan terdapat juga status pembayaran yaitu belum dibayar apabila mahasiswa telah melakukan pembayaran maka status pembayaran otomatis akan berubah menjadi lunas. Pada sisi kanan bawah terdapat tombol Bayar Sekarang untuk melanjutkan pembayaran.

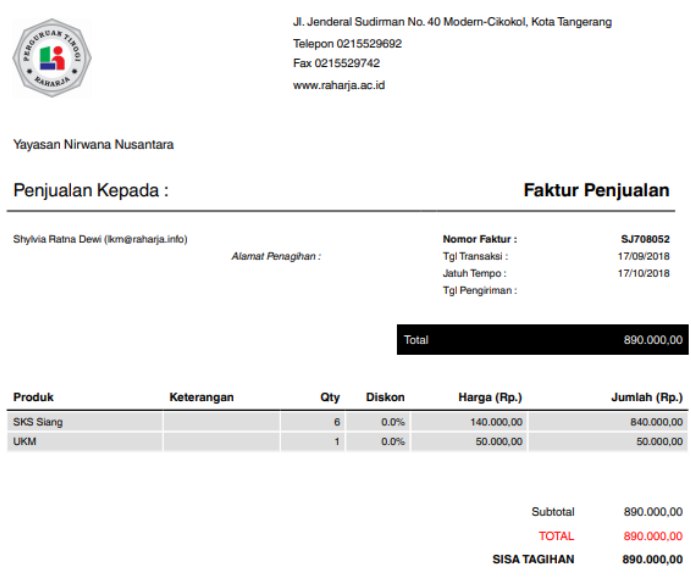

Gambar 9 . Tampilan Rincian

Pada halaman select payment terdapat juga rincian tagihan pembayaran dalam bentuk format PDF dimana terdapat penjelasan mengenai logo Perguruan Tinggi serta dilengkapi dengan alamat lengkap Perguruan Tinggi. Kemudian tertera nama mahasiswa yang ditagihkan dengan nomor faktur mahasiswa dimana setiap mahasiswa memiliki nomor faktur yang berbeda-beda guna memudahkan pihak Layanan Keuangan Mahasiswa mencari data. Yang tidak kalah penting terdapat juga tanggal transaksi atau tanggal dikirimnya tagihan pembayaran tersebut kepada email mahasiswa dan tanggal jatuh tempo pembayaran apabila mahasiswa melakukan pembayaran melewati batas tanggal jatuh tempo maka tidak mendapatkan diskon sebesar 5\%. Tujuan utama tampilan rincian tagihan pembayarandalam format PDF yaitu menampilkan rincian produk yang ditagihkan kepada mahasiswa pada semester ini seperti rincian tagihan SKS dengan jumlah yang di mampu mahasiswa pada semester ini, dan rincian tagihan lainnya. 


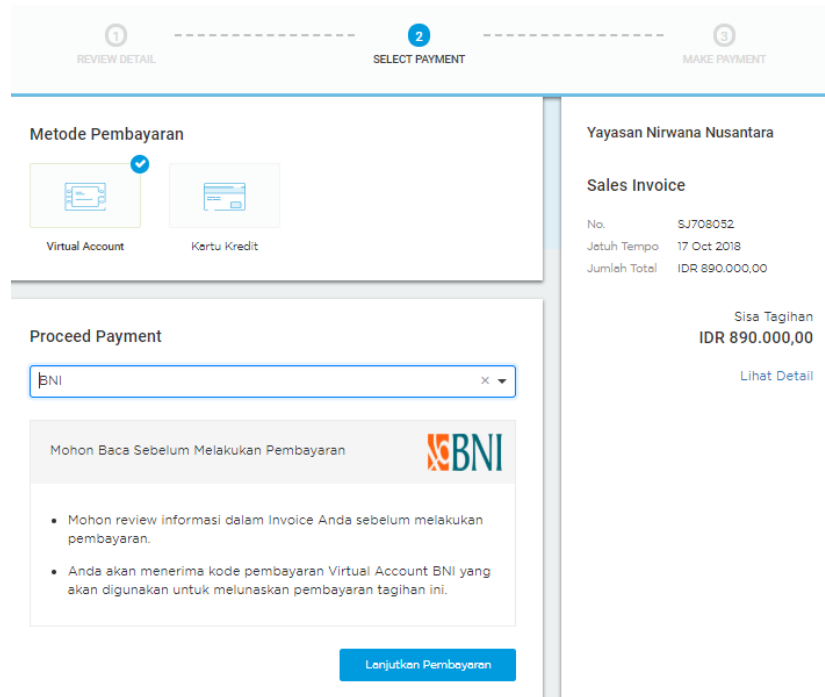

Gambar 10 .Halaman Metode Pembayaran pada Sistem

Apabila mahasiswa telah melakukan tekan tombol Bayar Sekarang pada halaman select payment, maka langkah selanjutnya yaitu memilih metode pembayaran sebelum melakukan transfer. Pada halaman metode pembayaran ini terdapat 2 (dua) metode pembayaran yaitu menggunakan Virtual Account dan Kartu kredit, namun pada sistem pembayaran online kali ini lebih berfokus pada metode pembayaran menggunakanVirtual Account. Kemudian terdapat 3 (tiga) pilihan Bank yang telah bekerja sama pada metode pembayaran Virtual Account ini yaitu Bank BNI, Mandiri, dan BRI. Dimana terdapat sebuah catatan penting apabila menggunakan Bank Mandiri hanya dapat dilakukan dengan transfer sesama Bank Mandiri, namun untuk Bank BNI dan BRI dapat dilakukan transfer dari berbagai jenis Bank. Setelah selesai memilih Bank tujuan, mahasiswa dapat melakukan tekan tombol Lanjutkan Pembayaran untuk mendapatkan informasi Nomor Virtual Account pada sistem.

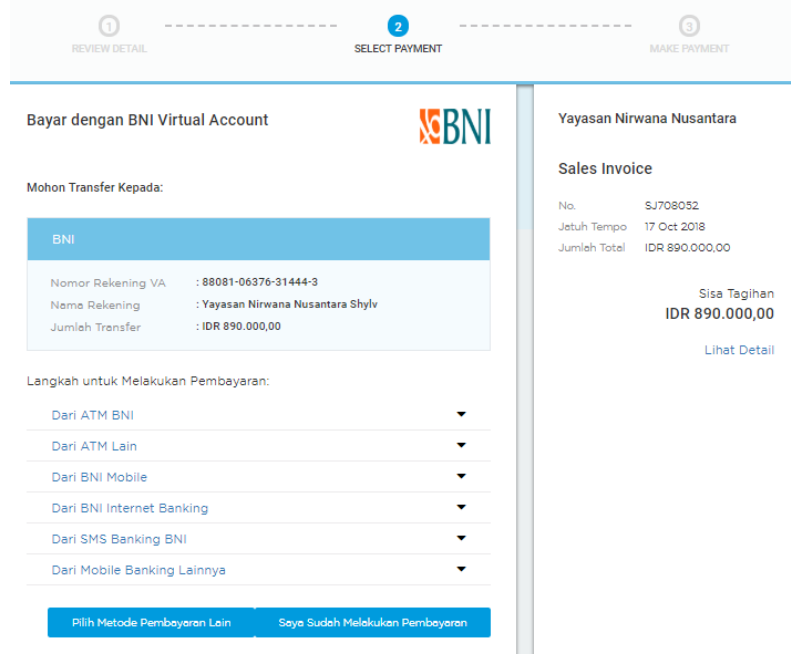

Gambar 11 . Halaman Informasi Nomor Virtual Account Tagihan Mahasiswa

Pada halaman ini ketika mahasiswa telah memilih salah satu bank, maka dapat melihat informasi mengenai nomor rekening Virtual Account yang telah di set up sebelumnya. Mahasiswa dapat melakukan transfer pada nomor rekening Virtual Account masing - masing dengan tata cara masukkan nomor Virtual
Account tanpa menggunakan garis strip dan pastikan tidak ada salah satu nomor yang tertinggal. Setelah selesai melakukan review pada tahap ini, mahasiswa dapat langsung melakukan pembayaran tagihan.

\section{PEMBAYARAN DITERIMA}

Dear Rulita Octipany-1611493889, Terima Kasih atas pembayaran Anda

Pembayar sudah di terima dan berhasil di akui!
$\begin{aligned} & \text { Tanggal dan Waktu } \\ & \text { Keterangan }\end{aligned}$
$\begin{aligned} & \text { 04/10/2018 } 02.16 \\ & \text { Jumlah Diterima }\end{aligned}$

Gambar 12 . Halaman Informasi Pembayaran Diterima

Pada halaman ini ketika mahasiswa telah berhasil melakukan pembayaran, dan saldo telah masuk pada rekening Perguruan Tinggi sehingga tagihan pada sistem Jurnal.id berubah menjadi paid. maka pihak kasir akan mengirimkan invoice berupa informasi bahwa pembayaran telah berhasil diterima. Kemudian mahasiswa dapat melakukan pengecekkan kembali apakah status pada format PDF sudah berubah menjadi lunas. Dengan begitu mahasiswa tidak perlu lagi menukar resi pembayaran untuk ditukar menjadi kwitansi.

\section{KESIMPULAN DAN SARAN}

Berdasarkan dari penjelasan yang telah penulis uraikan sebelumnya, maka penulis dapat memberikan kesimpulan yaitu metode pembayaran berbasis Cloud Accounting dapat memudahkan mahasiswa dalam melakukan pembayaran secara online dan real time serta memudahkan pihak kasir dalam proses pembukuan dan rekonsiliasi. serta saran dari penelitian tersebut, antara lain:

a. Pada pengembangan sistem selanjutnya terdapat fitur dan fasilitas yang lebih lengkap serta memudahkan dua belah pihak yaitu kasir dan mahasiswa dalam menggunakan sistem pembayaran ini

b. Pengembangan selanjutnya tagihan yang dikirimkan kepada mahasiswa dibuat lebih user friendly sehingga memudahkan mahasiswa dalam mengakses.

\section{UCAPAN TERIMA KASIH}

Penulis mengucapkan terima kasih kepada Sekolah Tinggi Manajemen Informatika dan Komputer Raharja beserta Jurnal.Id (Cloud Accounting) atas dukungan finansial dari penelitian ini melalui analisa sistem penelitiannya. 


\section{REFERENSI}

[1] Rahardja, U., Aini, Q., \& Thalia, M. B. (2018). Penerapan Menu Konfirmasi Pembayaran Online BerbasisYii pada Perguruan Tinggi. Creative Information Technology Journal, 4(3), 174-185.

[2] Rahardja, U. (2018). The Strategy of Enhancing Article Citation and H-Index on SINTA to Improve Tertiary Reputation. TELKOMNIKA (Telecommunication Computing Electronics and Control), 17(1).

[3] Yusup, M., Rahardja, U., \&Oktaviani, S. (2014). GO+ Dalam Menunjang Int+ Untuk Pengelolaan Data Cmb Pada Perguruan Tinggi. CCIT Journal, 8(1), 65-82.

[4] Rahardja, U., Harahap, E. P., \&Pratiwi, S. (2018). Pemanfaatan Mailchimp Sebagai Trend Penyebaran Informasi Pembayaran Bagi Mahasiswa Di Perguruan Tinggi. Technomedia Journal, 2(2), 38-51.

[5] Rahardja, U., Aini, Q., \& Thalia, M. B. (2018). Penerapan Menu Konfirmasi Pembayaran Online BerbasisYii pada Perguruan Tinggi. Creative Information Technology Journal, 4(3), 174-185.

[6] Tiara, K., Nurhaeni, T., \&Faradisa, Y. (2017). PENERAPAN GO+ BERBASIS WEB UNTUK MENINGKATKAN MUTU PELAYANAN LEMBAGA KEUANGAN MAHASISIWA. Technomedia Journal, 1(2), 90-1.

[7] Purves, T., Vandrevala, Z., Romanek, T., \& Kim, J. (2013). U.S. Patent Application No. 13/923,113.

[8] May, J., \& Flint, I. (2009). U.S. Patent No. 7,499,875. Washington, DC: U.S. Patent and Trademark Office.

[9] Jamison, E. W., Fortney, D. S., Vasavada, D. A., \& Kosowski, A. (2011). U.S. Patent No. 7,958,049. Washington, DC: U.S. Patent and Trademark Office.

[10] Johnston, D., Schmidt, M., Grosman, I., \& Ransom, B. (2012). U.S. Patent No. 8,108,274. Washington, DC: U.S. Patent and Trademark Office.

[11] Aini, Q., Graha, Y. I., \&Zuliana, S. R. (2017). Penerapan Absensi QR Code Mahasiswa Bimbingan Belajar pada Website berbasis YII Framework. Sisfotenika, 7(2), 207218.

[12] Rahardja, U., Aini, Q., \&Hardini, M. (2018). PENERAPAN SOFTWARE AKUNTANSI ONLINE SEBAGAI PENUNJANG PENCATATAN LAPORAN KEUANGAN. SISFOTENIKA, 8(2), 176-187.

[13] Rahardja, U., Aini, Q., \&Khoirunisa, A. (2017). Implementasi Business Intelligence Menggunakan High chart pada Sistem Penilaian Absensi berbasis YII
Framework. CSRID (Computer Science Research and Its Development Journal), 9(2), 115-124.

[14] U. Rahardja, A. Moein, and N. Lutfiani, "Leadership,Competency, Working Motivation and Performance of High Private Education Lecturer with Institution Accreditation B: Area Kopertis IV Banten Province,” Man India, vol. 97, no. 24,pp. 179-192

[15] U. Rahardja, M. Yusup, and Q. Aini, “Aplikasi Campus Learning System iOU ( integrated Online Ujian ) Dalam Mendukung Kegiatan E-Learning Education ( iDu ) Pada Perguruan Tinggi," CCIT J., vol. 7, no. 40, p. 16, 2014

[16] Rahardja, U., Aini, Q., \&Santoso, N. P. L. (2018). Pengintegrasian YII Framework Berbasis API pada Sistem Penilaian Absensi. SISFOTENIKA, 8(2), 140-152.

[17] Rachmawati, S., \& Nurjanah, N. (2017). IMPLEMENTASI DATA KEUANGAN DENGAN ZAHIR ACCOUNTING PADA PT. ANUGERAH ANALISIS SEMPURNA. JURNAL AKUNTANSI, EKONOMI dan MANAJEMEN BISNIS, 5(2), 267-273.

[18] Rahardja, U., Tiara, K., \& Rosalinda, I. A. (2016). Pemanfaatan Google Scholar Dan Citation Dalam Memenuhi Kebutuhan Pembuatan Skripsi Mahasiswa Pada Perguruan Tinggi. Technomedia Journal, 1(1), 95-113.

[19] Damanik, E. (2012). Perancangan Sistem Informasi Pembayaran Online menggunakan PAYMENT GATEWAY. JSM (Jurnal SIFO Mikroskil), 13(1), 63-72.

[20] Sudarno, B. E. P. (2012). Analysis Tracking Online Payment System. International Journal Of Scientific \& Technology Research (IJSTR) Volume, 1 .

[21] Rahardja, U., Aini, Q., \&Enay, N. (2017). Optimalisasi Dashboard pada SistemPenilaianSebagai Media Informasi di Perguruan Tinggi. Sisfotenika, 7(2), 167-176.

[22] Khakim, K. N., \& Hadiprajitno, B. (2011). Analisis FaktorFaktor Yang Mempengaruhi Penerimaan Dan Penggunaan Software Akuntansi MyobDengan Menggunakan Pendekatan Technology Acceptance Model (Tam) (Doctoral dissertation, Universitas Diponegoro).

[23] Aini, Q., Rahardja, U., Moeins, A., \& Wardani, A. M. (2018). Penerapan Data Market Query (DMQ) pada Sistem Penilaian Berbasis Yii Framework. InfoTekJar: Jurnal Nasional Informatika dan Teknologi Jaringan, 3(1), 26-31. 